\title{
The Role of RANKL and Involvement of Cementum in Orthodontic Root Resorption
}

\author{
Masaru Yamaguchi ${ }^{1, *(\mathbb{D})}$ and Hiroyuki Mishima ${ }^{2}$ (D) \\ 1 Ginza Orthodontic Clinic, Ginza Granvia 6F, 3-3-14 Ginza, Chuo-ku, Tokyo 104-0061, Japan \\ 2 Department of Dental Engineering, Tsurumi University School of Dental Medicine, \\ Yokohama 230-8501, Japan; mishima-h@tsurumi-u.ac.jp \\ * Correspondence: yamaguchimasaru3@gmail.com; Tel.: +81-3-3567-5454
}

Citation: Yamaguchi, M.; Mishima,

$\mathrm{H}$. The Role of RANKL and Involvement of Cementum in Orthodontic Root Resorption. Appl. Sci. 2021, 11, 7244. https://doi.org/ 10.3390/app11167244

Academic Editor: Bruno Chrcanovic

Received: 23 July 2021

Accepted: 2 August 2021

Published: 6 August 2021

Publisher's Note: MDPI stays neutral with regard to jurisdictional claims in published maps and institutional affiliations.

Copyright: (c) 2021 by the authors. Licensee MDPI, Basel, Switzerland. This article is an open access article distributed under the terms and conditions of the Creative Commons Attribution (CC BY) license (https:// creativecommons.org/licenses/by/ $4.0 /)$.
Abstract: Orthodontic root resorption (ORR) is an unintended side effect of orthodontic treatment, and severe ORR can affect treatment outcome. Receptor activator of nuclear factor kappa-B ligand (RANKL) has been detected in the resorbed cementum and periodontal (PDL) tissues exposed to excessive orthodontic forces. Recent studies have demonstrated that PDL cells and cementoblasts express RANKL that may play a role in ORR during orthodontic tooth movement. It is known that the hardness of cementum in human maxillary premolars differs among individuals. Furthermore, this difference has been reported to be attributed to differences in the calcium (Ca)/phosphorus (P) ratio. A correlation was observed between the Vickers hardness and $\mathrm{Ca} / \mathrm{P}$ ratio of the cementum in the apical region. These findings suggest that cementum hardness and the $\mathrm{Ca} / \mathrm{P}$ ratio may be indirectly involved in ORR caused by orthodontic forces. In this review, it aims to identify the role of RANKL and involvement of cementum in ORR.

Keywords: orthodontic root resorption; RANKL; cementum; orthodontic tooth movement

\section{Introduction}

Orthodontic root resorption (ORR) was first described in 1914 by Ottolengui [1]. It is characterized by surface resorption with a loss of cementum that is irreversible when the dentin is involved [2]. Several studies have examined the etiology and mechanism of ORR. In an epidemiological study conducted by Kaley and Phillips [3], all patients who underwent comprehensive orthodontic treatment presented with root shortening, and 3\% of all patients with severe root resorption (shortening by more than one-quarter of the root length) presented with root shortening in the maxillary central incisors.

The receptor activator of nuclear factor-kappa-B ligand (RANKL), and its two receptors RANK and osteoprotegerin (OPG), are known to be involved in the process of bone remodeling [4]. The RANKL/RANK/OPG system plays an essential role in the induction of bone remodeling. RANKL is a downstream regulator of the formation and activation of osteoclasts, through which many hormones and cytokines exert their bone resortive effect. RANKL is expressed in the osteoblast cell lineage, and it exerts its effect by binding to the RANK receptor on osteoclasts. This binding leads to a rapid differentiation of the hematopoietic osteoclast precursors into mature osteoclasts. Numerous studies have investigated the cause and mechanism of ORR; in vitro and in vivo studies have reported that RANKL expression in periodontal (PDL) cells plays a significant role in the occurrence of ORR. Recent studies reported that cementoblasts also produced RANKL in response to compressive force and are involved in the ORR.

Recent studies in humans have reported the presence of individual differences in the hardness of cementum near the apex and particularly the calcium $(\mathrm{Ca}) /$ phosphorus $(\mathrm{P})$ ratio. A correlation was observed between the Vickers hardness and $\mathrm{Ca} / \mathrm{P}$ ratio of the cementum in the apical region [5-7]. These findings suggest that the cementum hardness 
and the $\mathrm{Ca} / \mathrm{P}$ ratio may be involved in the occurrence of ORR. In this paper, it aims to review the role of RANKL and the involvement of cementum in ORR.

\section{Information Sources and Literature Search}

Although this review is not a systematic review, PubMed was searched up to February 2021. Searches were undertaken with no restrictions on year, publication status, or language. The key word and their combinations used for articles' search were: orthodontic root resorption, RANKL, cementum, periodontal ligament, orthodontic tooth movement. Furthermore, the following journals were searched manually: "American Journal of Orthodontics and Dentofacial Orthopedics", "Angle Orthodontists", "European Journal of Orthodontics", Journal of World Federation of Orthodontists, and Journal of Dental Research.

\section{Risk Factors of Orthodontic Root Resorption (ORR)}

ORR is one of the accidental signs observed during orthodontic treatment: severe ORR can affect the outcome of treatment. Samandara et al. [8] reported that ORR was a multifactorial complication that occurred when multiple (patient- or treatment-related) risk factors overlapped (Figure 1). As presented in Figure 2, if the patient's sensitivity to root resorption is compared to a glass and water, the risk factor (water droplets) drops, and the glass (sensitivity) is gradually filled when orthodontic treatment is started. Root resorption does not occur until the glass is full, but root resorption occurs when it spills (Figure 2).

\section{【Risk factors of ORR】}

\section{Patient-related factors}

1) Genetics

2) Sex

3) Age

4) Tooth type

5) Systemic factors

6) Root morphology

7) History of trauma or previous root resorption

\section{Treatment-related factors}
1) Appliance type
2) Treatment duration
3) Type of tooth movement
4) Applied force magnitude
5) Duration of force application
6) Extraction treatment

\section{Others}

Figure 1. Risk factors of ORR [8].
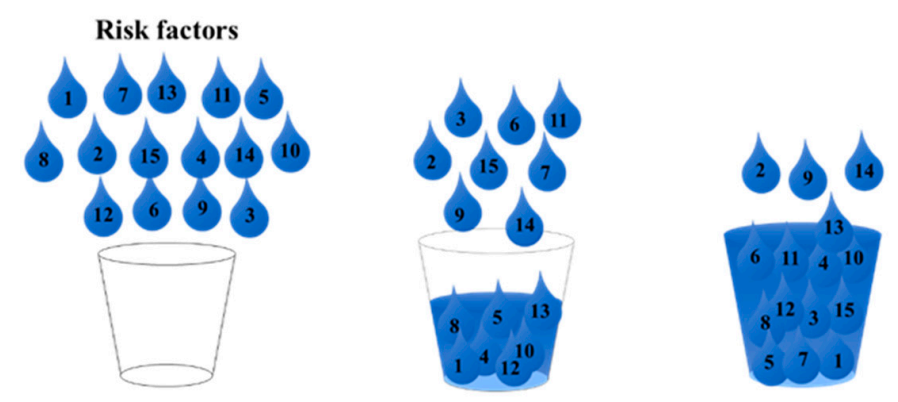

Start orthodontic treatment:

During orthodontic treatment:

there is nothing in the glass

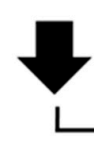

there is half-full glass

the glass is full to

overflow

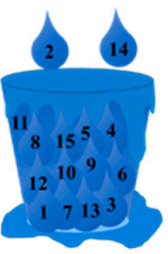

The water overflows the glass

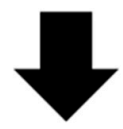

Not occurrence of ORR

\section{Occurrence of ORR}

Figure 2. The schema of occurrence of ORR. A gradual increase in the number of risk factors (water droplets) following orthodontic treatment slowly leads to root resorption (Figure 2). 


\section{The Receptor Activator of Nuclear Factor Kappa-B Ligand (RANKL) in Bone Resorption and Orthodontic Tooth Movement}

RANKL and its receptor RANK are expressed in osteoblasts and the precursor osteoclasts, respectively. They are the key factors that stimulate the formation of osteoclast and osteoclastogenesis $[9,10]$. RANKL and the macrophage colony-stimulating factor (MCSF) are involved in the formation of osteoclasts [11]. Osteoprotegerin (OPG), a soluble tumor necrosis factor (TNF) receptor-like molecule, binds to RANK and inhibits RANK/RANKL interactions [12], thereby preventing the differentiation and activation of osteoclasts. Studies in animals using transgenic mice and gene knockout mice have demonstrated that RANK, RANKL, and OPG play a significant role in regulating the formation of osteoclast [13-15].

Kanzaki et al. [16] demonstrated that compressive forces upregulated RANKL expression by induction of COX-2 expression in human PDL cells in vitro. In addition, these forces can increase RANKL and decrease OPG secretion in human PDL cells in vitro [17,18]. Animal studies [19] have demonstrated the expression of RANKL in periodontal tissues during rat experimental tooth movement, and that the extent of experimental tooth movement in rats was accelerated by the transfer of the RANKL gene, and inhibited by the transfer of the OPG gene, to the periodontal tissue $[20,21]$. The levels of RANKL and OPG in GCF have been found to be increased and decreased, respectively, during experimental orthodontic tooth movement [22]. Therefore, it has been suggested that the RANK/RANKL/OPG system is directly involved in the regulation of orthodontic tooth movement.

\section{RANKL Produced by PDL Cells and Cementoblasts in ORR}

Previous studies have reported that excessive compressive force enhanced PGE2, IL-1, IL-6, and TNF- $\alpha$ expression in PDL cells [23-26]. These factors stimulate RANKL expression in hPDL cells. Therefore, it can be concluded that PGE2, IL-1, IL-6, TNF- $\alpha$, and RANK play important roles in the orthodontic tooth movement [27-29]. Furthermore, Yamaguchi et al. [22] reported that compressive force resulted in RANKL expression and caused an increase in osteoclastogenesis in vitro. According to Kikuta et al. [28], excessive orthodontic forces stimulated the process of ORR via RANKL and IL-6 expression in hPDL cells. Therefore, PDL cells that are exposed to excessive compressive forces express inflammatory cytokines, which exacerbates the process of ORR.

Recent studies have demonstrated that both PDL cells and cementoblasts express RANKL. Diercke et al. [30] demonstrated that IL-1 $\beta$ and compressive forces induced significant RANKL expression in cementoblasts. Minato et al. [31] and Iwane et al. [32] reported that exposure of cementoblasts to excessive orthodontic forces leads to the expression of large amounts of RANKL and IL-6, which could induce ORR; therefore, OIIRR is caused by both PDL cells and cementoblasts. In addition, Yamaguchi et al. [22] reported that ORR could be due to both PDL cells and cementoblasts, probably via RANKL expression in these cells (Figure 3).

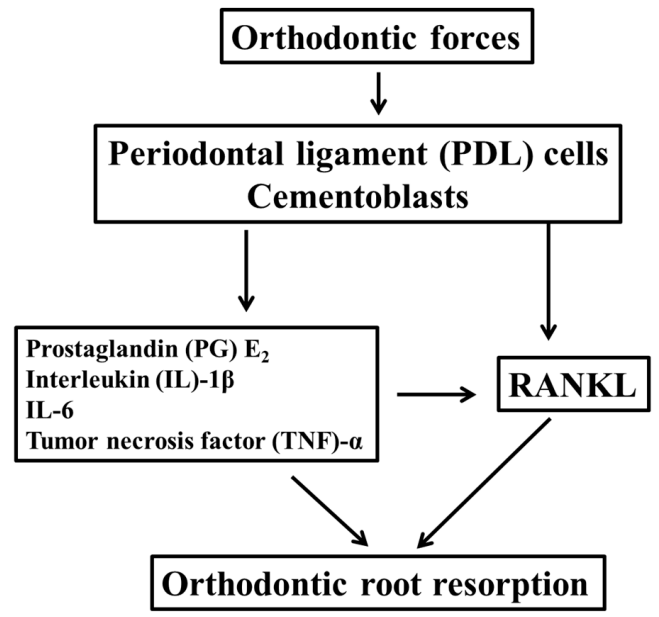

Figure 3. The role of RANKL in ORR. 


\section{Repair of Resorbed Cementum by Cementoblasts}

When no more hyaline tissue presents and/or the force level diminishes, the resorption process stops and the repair of cementum starts [33,34]. Initially, the cementoclasts/odontoclasts detached from the resorbed lacunae [35]; they die due to apoptosis [36]. After detachment of cementoclasts/odontoclasts, early cementum repair starts with fibroblast-like cells $[33,34]$. These fibroblast-like cementoblasts secrete noncollagenous matrix proteins, such as osteopontin and bone sialoprotein, filling the spaces in the residual collagen fibril structure [37]. Subsequently, the cementoblasts secrete collagen fibrils, including a thin cementoid repair matrix [37]. Mineralization ensues with hydroxyapatite crystals development and growth between the collagen fibrils [38], forming reparative cementum of the cellular intrinsic fiber type $[39,40]$.

\section{Involvement of Cementum in ORR}

\subsection{The Hardness of Cementum}

As a new attempt, we focused on the relationship between root resorption and cementum hardness from a different perspective. The cementum, which covers the root surface, is composed of thin calcified tissue produced by cementoblasts. The apical third of the root is covered with cellular cementum, whereas the coronary third of the root is covered with noncellular cementum. Active cellular cementum depends on blood circulation. Generally, the mineralized surface of the cementum is more resorbed in the apical part of the root following orthodontic tooth movement than in other regions in humans. Hardness may be a major factor affecting the structure of cementum, particularly during root resorption caused by orthodontic forces.

According to the group of Darendeliler et al. [41-44], substantial individual variations in the occurrence, surface extension, and depth of root resorption have been reported in some studies [41-44]. The hardness (soft, moderate, and hard) and tissue mineral density (TMD) of the cementum in the apical region of the root have been measured using the dynamic micro-indentation method and X-ray $\mu \mathrm{CT}$ analysis, respectively. The cementum hardness values were lower in the soft and moderate groups than in a hard group [5], and the X-ray $\mu \mathrm{CT}$ analysis revealed that the teeth in the hard group had higher TMD values than those in the other two groups [6]. Therefore, the hardness of the cementum may be related to the occurrence of ORR. Further studies are necessary to investigate which cementum hardness and TMD contribute to ORR incidence clinically, in animal or human models.

\subsection{The Difference of Chemical Composition of Cementum}

Rex et al. [45] demonstrated significant individual variations in the hardness of the cementum in the first premolars based on $\mathrm{Ca}, \mathrm{P}$, and fluorine $(\mathrm{F})$ concentrations, with a decreasing gradient in these concentrations from the cervical to the apical third of the root. Subsequently, to elucidate the relationship between cementum hardness and degree of resorption, Yao-Umezawa et al. [7] used a pit formation assay to demonstrate that the resorbed area in a soft group was increased to a greater extent than those in the moderate and hard groups.

Scanning electron microscopy-energy spectroscopy has gained considerable importance in dental research $[46,47]$. Yao-Umezawa et al. [7] reported that the $\mathrm{Ca} / \mathrm{P}$ ratio of the cementum in a soft group was decreased to a greater extent than those in moderate and hard groups. A correlation was observed between the Vickers hardness and $\mathrm{Ca} / \mathrm{P}$ ratio of cementum in the apical region $(r=0.741, p<0.01)$. Alvarez-Perez et al. [48] reported that the $\mathrm{Ca} / \mathrm{P}$ ratio of cementum in the apical region ranged between 1.3 and 1.6. Therefore, a low hardness value (soft cementum) may be attributed to a low $\mathrm{Ca} / \mathrm{P}$ ratio.

Considering the abovementioned results, individual variations in the hardness and $\mathrm{Ca} / \mathrm{P}$ ratio of cementum may influence the resistance or susceptibility to root resorption and could be involved in root resorption caused by orthodontic forces. Yamaguchi et al. [5] demonstrated a positive correlation between the respective hardness of enamel and cemen- 
tum in humans (hardness: $\mathrm{r}=0.551, p<0.01$, and elastic modulus, $\mathrm{r}=0.552, p<0.01$ ). If cementum hardness can be estimated based on the value of enamel, it may be possible to accurately evaluate the risk of root resorption in each patient during orthodontic treatment. Therefore, orthodontists would be able to predict root resorption and provide an effective and safe treatment. Further studies are needed to elucidate the relationship between the enamel and cementum, particularly regarding their mechanical properties.

\section{Is Cementum the Last Bastion against ORR?}

Severe root resorption may not necessarily be observed, even after applying heavy force during treatment. On the one hand, Beck and Harris [49] did not show any relationship between root resorption and heavy force. Weiland [50] reported that orthodontic force, up to a magnitude of $200 \mathrm{cN}$, may not be decisive for root resorption. Brezniakand Wasserstein [2] and Owman-Moll et al. [51] also reported that there was no root resorption difference detected while using low and high forces (50 and $200 \mathrm{~g}$ ). On the other hand, Paetyangkul et al. [52] established that the distribution of resorbed lacunae was directly related to the magnitude of a force; resorbed lacunae developed more quickly in the case of heavy forces. One of the explanations for these conflicting phenomena may be resistance to cementum hardness. Regarding the degree of tooth root resorption, the greater the amount of RANKL expressed in PDL cells or cementoblasts, the greater the amount of the resorption. Patients with soft cementum have a higher amount of root resorption as compared with patients with hard cementum. Even small amounts of RANKL expressed in response to light orthodontic forces can cause root resorption in soft cementum teeth. Therefore, cementum hardness is one of the factors involved in the development of root resorption and may be the "last bastion" of root resorption (Figure 4). Additional studies are needed to evaluate the relationship between ORR and cementum hardness.

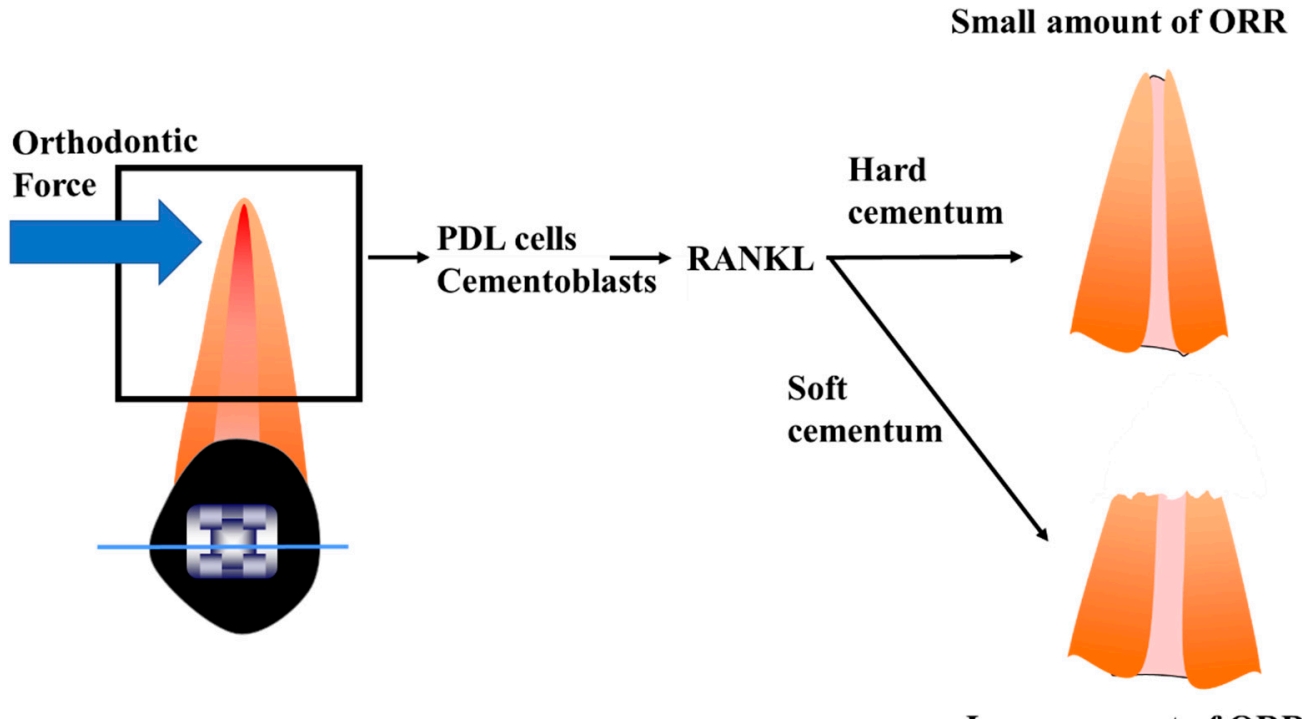

Large amount of ORR

Figure 4. Schematic figure showing the presumed role of cementum in ORR. Despite a similar amount of RANKL expression, teeth with hard cementum may present with less root resorption than those with soft cementum. Thus, hard cementum may be the last defense against ORR.

\section{Conclusions}

Cementoblasts exposed to orthodontic forces exacerbate ORR via RANKL, while the cementum with higher $\mathrm{Ca} / \mathrm{P}$ ratio and TMD values may resist against ORR. Additional studies are required to investigate which types of cementum (cementoblasts) contribute to the incidence of ORR clinically, in animal or human models. 
Author Contributions: Conceptualization, M.Y. and H.M.; writing-original draft preparation, review and editing, M.Y. and H.M. Both authors have read and agreed to the published version of the manuscript.

Funding: This research was supported, in part, by Grants-in-Aid for Scientific Research from the Japan Society for the Promotion of Science (23593044, 25463200, 16K11795).

Institutional Review Board Statement: The study was conducted according to the guidelines of the Declaration of Helsinki, and approved by the Ethics Committee of Nihon University School of Dentistry at Matsudo (EC 15-001).

Informed Consent Statement: Written informed consent has been obtained from the patient to publish this paper.

Acknowledgments: The author would like to thank Shinichi Fukasawa for the suggestion about orthodontic root resorption.

Conflicts of Interest: The authors declare no conflict of interest.

\section{Abbreviations}

ORR, orthodontic root resorption; PDL, periodontal ligament; RANKL, receptor activator of nuclear factor ligand; OTM, orthodontic tooth movement.

\section{References}

1. Ottolengui, R. The physiological and pathological resorption of tooth roots. Drent. Items Interest 1914, 36, 322-362.

2. Brezniak, N.; Wasserstein, A. Orthodontically induced inflammatory root resorption. Part II: The clinical aspects. Angle Orthod. 2002, 72, 180-184.

3. Kaley, J.; Phillips, C. Factors related to root resorption in edgewise practice. Angle Orthod. 1991, 61, 125-132.

4. Alhashimi, N.; Frithiof, L.; Brudvik, P.; Bakhiet, M. Orthodontic tooth movement and de novo synthesis of proinflammatory cytokines. Am. J. Orthod. Dentofac. Orthop. 2001, 119, 307-312. [CrossRef] [PubMed]

5. Yamaguchi, M.; Yao-Umezawa, E.; Tanimoto, Y.; Shimizu, M.; Kikuta, J.; Hikida, T.; Takahashi-Hikida, M.; Horihata, S.; Suzuki, K.; Kasai, K. Individual Variations in the Hardness and Elastic Modulus of the Human Cementum. J. Hard Tissue Biol. 2016, 25, 345-350. [CrossRef]

6. Yamaguchi, M.; Mishima, H. Hardness Variations and Chemical Compositional Changes in Human Cementum. J. Oral Tissue Eng. 2021, in press.

7. Yao-Umezawa, E.; Yamaguchi, M.; Shimizu, M.; Kikuta, J.; Suzuki, K.; Kasai, K. Relationship between root resorption and individual variation in the calcium/phosphorous ratio of cementum. Am. J. Orthod. Dentofac. Orthop. 2017, 152, 465-470. [CrossRef]

8. Samandara, A.; Papageorgiou, S.N.; Ioannidou-Marathiotou, I.; Kavvadia-Tsatala, S.; Papadopoulos, M. Evaluation of orthodontically induced external root resorption following orthodontic treatment using cone beam computed tomography (CBCT): A systematic review and meta-analysis. Eur. J. Orthod. 2019, 41, 67-79. [CrossRef]

9. Lacey, D.L.; Timms, E.; Tan, H.L.; Kelley, M.J.; Dunstan, C.R.; Burgess, T.; Elliott, R.; Colombero, A.; Elliott, G.; Scully, S.; et al. Osteoprotegerin ligand is a cytokine that regulates osteoclast differentiation and activation. Cell 1998, 93, 165-176. [CrossRef]

10. Yasuda, H.; Shima, N.; Nakagawa, N.; Yamaguchi, K.; Kinosaki, M.; Mochizuki, S.-I.; Tomoyasu, A.; Yano, K.; Goto, M.; Murakami, A.; et al. Osteoclast differentiation factor is a ligand for osteoprotegerin/osteoclastogenesis-inhibitory factor and is identical to TRANCE/RANKL. Proc. Natl. Acad. Sci. USA 1998, 95, 3597-3602. [CrossRef] [PubMed]

11. Haynes, D.R.; Atkins, G.J.; Loric, M.; Crotti, T.N.; Geary, S.M.; Findlay, D.M. Bidirectional signaling between stromal and hemopoietic cells regulates interleukin-1 expression during human osteoclast formation. Bone 1999, 25, 269-278. [CrossRef]

12. Yasuda, H.; Shima, N.; Nakagawa, N.; Mochizuki, S.-I.; Yano, K.; Fujise, N.; Sato, Y.; Goto, M.; Yamaguchi, K.; Kuriyama, M.; et al. Identity of Osteoclastogenesis Inhibitory Factor (OCIF) and Osteoprotegerin (OPG): A Mechanism by which OPG/OCIF Inhibits Osteoclastogenesis in Vitro. Endocrinology 1998, 139, 1329-1337. [CrossRef]

13. Bucay, N.; Sarosi, I.; Dunstan, C.R.; Morony, S.; Tarpley, J.; Capparelli, C.; Scully, S.; Tan, H.L.; Xu, W.; Lacey, D.L.; et al. osteoprotegerindeficient mice develop early onset osteoporosis and arterial calcification. Genes Dev. 1998, 12, 1260-1268. [CrossRef]

14. Kong, Y.-Y.; Yoshida, H.; Sarosi, I.; Tan, H.-L.; Timms, E.; Capparelli, C.; Morony, S.; Oliveira-Dos-Santos, A.J.; Van, G.; Itie, A.; et al . OPGL is a key regulator of osteoclastogenesis, lymphocyte development and lymph-node organogenesis. Nat. Cell Biol. 1999, 397, 315-323. [CrossRef] [PubMed]

15. Mizuno, A.; Amizuka, N.; Irie, K.; Murakami, A.; Fujise, N.; Kanno, T.; Sato, Y.; Nakagawa, N.; Yasuda, H.; Mochizuki, S.; et al. Severe osteoporosis in mice lacking osteoclastogenesis inhibitory factor/osteoprotegerin. Biochem. Biophys. Res. Commun. 1998, 247, 610-615. [CrossRef] [PubMed] 
16. Kanzaki, H.; Chiba, M.; Shimizu, Y.; Mitani, H. Periodontal ligament cells under mechanical stress induce osteoclastogenesis by receptor activator of nuclear factor kappaB ligand up-regulation via prostaglandin E2 synthesis. J. Bone. Miner. Res. 2002, 17, 210-220. [CrossRef] [PubMed]

17. Nishijima, Y.; Yamaguchi, M.; Kojima, T.; Aihara, N.; Nakajima, R.; Kasai, K. Levels of RANKL and OPG in gingival crevicular fluid during orthodontic tooth movement and effect of compression force on releases from periodontal ligament cells in vitro. Orthod. Craniofac. Res. 2006, 9, 63-70. [CrossRef] [PubMed]

18. Yamaguchi, M.; Aihara, N.; Kojima, T.; Kasai, K. RANKL Increase in Compressed Periodontal Ligament Cells from Root Resorption. J. Dent. Res. 2006, 85, 751-756. [CrossRef]

19. Aihara, N.; Otsuka, A.; Yamaguchi, M. Localization of RANKL and cathepsin K, B, and L in rat periodontal tissues during experimental tooth movement. Orthod. Waves 2005, 64, 107-113.

20. Kanzaki, H.; Chiba, M.; Takahashi, I.; Haruyama, N.; Nishimura, M.; Mitani, H. Local OPG Gene Transfer to Periodontal Tissue Inhibits Orthodontic Tooth Movement. J. Dent. Res. 2004, 83, 920-925. [CrossRef]

21. Kanzaki, H.; Chiba, M.; I Arai, K.; Takahashi, I.; Haruyama, N.; Nishimura, M.; Mitani, H. Local RANKL gene transfer to the periodontal tissue accelerates orthodontic tooth movement. Gene Ther. 2006, 13, 678-685. [CrossRef]

22. Yamaguchi, M. RANK/RANKL/OPG during orthodontic tooth movement. Orthod. Craniofac. Res. 2009, 12, 113-119. [CrossRef]

23. Long, P.; Liu, F.; Piesco, N.P.; Kapur, R.; Agarwal, S. Signaling by mechanical strain involves transcriptional regulation of proinflammatory genes in human periodontal ligament cells in vitro. Bone 2002, 30, 547-552. [CrossRef]

24. Yamamoto, T.; Kita, M.; Kimura, I.; Oseko, F.; Terauchi, R.; Takahashi, K.; Kubo, T.; Kanamura, N. Mechanical stress induces expression of cytokines in human periodontal ligament cells. Oral Dis. 2006, 12, 171-175. [CrossRef]

25. Kunii, R.; Yamaguchi, M.; Tanimoto, Y.; Asano, M.; Yamada, K.; Goseki, T.; Kasai, K. Role of interleukin-6 in orthodontically induced inflammatory root resorption in humans. Korean J. Orthod. 2013, 43, 294-301. [CrossRef]

26. Tsukada, M.; Kikuta, J.; Shimizu, M.; Hikida, T.; Nakayama, E.; Iwane, T.; Kasai, K. TGF- $\beta 1$ Induces Orthodontic Root Resorption through RANKL and IL-6 Production in hPDL Cells. Int. J. Oral-Med. Sci. 2021, 19, 278-287. [CrossRef]

27. Fukushima, H.; Jimi, E.; Okamoto, F.; Motokawa, W.; Okabe, K. IL-1induced receptor activator of NF-kappa B ligand in human periodontal ligament cells involves ERK-dependent PGE2 production. Bone 2005, 36, 267-275. [CrossRef]

28. Kikuta, J.; Yamaguchi, M.; Shimizu, M.; Yoshino, T.; Kasai, K. Notch Signaling Induces Root Resorption via RANKL and IL-6 from hPDL Cells. J. Dent. Res. 2014, 94, 140-147. [CrossRef]

29. Mitsuhashi, M.; Yamaguchi, M.; Kojima, T.; Nakajima, R.; Kasai, K. Effects of HSP70 on the compression force-induced TNF- $\alpha$ and RANKL expression in human periodontal ligament cells. Inflamm. Res. 2011, 60, 187-194. [CrossRef] [PubMed]

30. Diercke, K.; Kohl, A.; Lux, C.J.; Erber, R. IL-1beta and compressive forces lead to a significant induction of RANKL-expression in primary human cementoblasts. J. Orofac. Orthop. 2012, 73, 397-412. [CrossRef]

31. Minato, Y.; Yamaguchi, M.; Shimizu, M.; Kikuta, J.; Hikida, T.; Hikida, M.; Suemitsu, M.; Kuyama, K.; Kasai, K. Effect of caspases and RANKL induced by heavy force in orthodontic root resorption. Korean J. Orthod. 2018, 48, 253-261. [CrossRef]

32. Iwane, T.; Kikuta, J. Notch Signaling Response to Heavy Compression Force Induces Orthodontic Root Resorption via RANKL and IL-6 from Cementoblasts. Int. J. Oral-Med. Sci. 2020, 18, 287-295. [CrossRef]

33. Brudvik, P.; Rygh, P. Transition and determinants of orthodontic root resorption-Repair sequence. Eur. J. Orthod. 1995, 17, 177-188. [CrossRef]

34. Brudvik, P.; Rygh, P. The repair of orthodontic root resorption: An ultrastructural study. Eur. J. Orthod. 1995, 17, 189-198. [CrossRef] [PubMed]

35. Sahara, N.; Toyoki, A.; Ashizawa, A.; Deguchi, T.; Suzuki, K. Cytodifferentiation of the odontoclast prior to the shedding of human deciduous teeth: An ultrastructural and cytochemical study. Anat. Rec. 1996, 244, 33-49. [CrossRef]

36. Noxon, S.J.; King, G.J.; Gu, G.; Huang, G. Osteoclast clearance from periodontal tissues during orthodontic tooth movement. Am. J. Orthod. Dentofac. Orthop. 2001, 120, 466-476. [CrossRef]

37. Jäger, A.; Kunert, D.; Friesen, T.; Zhang, D.; Lossdörfer, S.; Götz, W. Cellular and extracellular factors in early root resorption repair in the rat. Eur. J. Orthod. 2008, 30, 336-345. [CrossRef]

38. Bosshardt, D.D.; Zalzal, S.; Mckee, M.D.; Nanci, A. Developmental appearance and distribution of bone sialoprotein and osteopontin in human and rat cementum. Anat. Rec. 1998, 250, 13-33. [CrossRef]

39. Owman-Moll, P.; Kurol, J.; Lundgren, D. Repair of orthodontically induced root resorption in adolescents. Angle Orthod. 1995, 65, 403-410. [CrossRef]

40. Bosshardt, D.D.; Schroeder, H.E. Cementogenesis reviewed: A comparison between human premolars and rodent molars. Anat. Rec. 1996, 245, 267-292. [CrossRef]

41. Chan, E.; Darendeliler, M.A. Physical properties of root cementum: Part 5. Volumetric analysis of root resorption craters after application of light and heavy orthodontic forces. Am. J. Orthod. Dentofac. Orthop. 2005, 127, 186-195. [CrossRef]

42. Chutimanutskul, W.; Darendeliler, M.A.; Swain, M.V.; Shen, G.; Petocz, P. Physical properties of human premolar cementum: Hardness and elasticity. Aust. Orthod. J. 2005, 21, 117-121.

43. Malek, S.; Darendeliler, M.A.; Swain, M. Physical properties of root cementum: Part I. A new method for 3-dimensional evaluation. Am. J. Orthod. Dentofac. Orthop. 2001, 120, 198-208. [CrossRef] [PubMed] 
44. Darendeliler, M.A.; Kharbanda, O.P.; Chan, E.K.; Srivicharnkul, P.; Rex, T.; Swain, M.V.; Jones, A.S.; Petocz, P. Root resorption and its association with alterations in physical properties, mineral contents and resorption craters in human premolars fol-lowing application of light and heavy controlled orthodontic forces. Orthod. Craniofac. Res. 2004, 7, 79-97. [CrossRef]

45. Rex, T.; Kharbanda, O.P.; Petocz, P.; Darendeliler, M.A. Physical properties of root cementum: Part Quantitative analysis of the mineral composition of human premolar cementum. Am. J. Orthod. Dentofac. Orthop. 2005, 127, 177-185. [CrossRef]

46. Gasga, J.R.; Carbajal-De-La-Torre, G.; Bres, E.; Gil-Chavarria, I.M.; Rodríguez-Hernández, A.G.; García-García, R. STEM-HAADF electron microscopy analysis of the central dark line defect of human tooth enamel crystallites. J. Mater. Sci. Mater. Med. 2008, 19, 877-882. [CrossRef] [PubMed]

47. Schüpbach, P.; Oppenheim, F.G.; Lendenmann, U.; Lamkin, M.S.; Yao, Y.; Guggenheim, B. Electron-microscopic demonstration of proline-rich proteins, statherin, and histatins in acquired enamel pelliclesin vitro. Eur. J. Oral Sci. 2001, 109, 60-68. [CrossRef]

48. Alvarez-Pérez, M.A.; Alvarez-Fregoso, O.; Ortiz-López, J.; Arzate, H. X-ray microanalysis of human cementum. Microsc. Microanal. 2005, 11, 313-318. [CrossRef] [PubMed]

49. Beck, B.W.; Harris, E.F. Apical root resorption in orthodontically treated subjects: Analysis of edgewise and light wire mechanics. Am. J. Orthod. Dentofac. Orthop. 1994, 105, 350-361. [CrossRef]

50. Weiland, F. External root resorptions and orthodontic forces: Correlations and clinical consequences. Prog. Orthod. 2006, 7, 156-163.

51. Owman-Moll, P.; Kurol, J.; Lundgren, D. The effects of a four-fold increased orthodontic force magnitude on tooth movement and root resorptions. An intraindividual study in adolescents. Eur. J. Orthod. 1996, 18, 287-294. [CrossRef] [PubMed]

52. Paetyangkul, A.; Türk, T.; Elekdag-Turk, S.; Jones, A.S.; Petocz, P.; Cheng, L.L.; Darendeliler, M.A. Physical properties of root cementum: Part 16. Comparisons of root resorption and resorption craters after the application of light and heavy continuous and controlled orthodontic forces for 4, 8, and 12 weeks. Am. J. Orthod. Dentofac. Orthop. 2011, 139, e279-e284. [CrossRef] [PubMed] 